\title{
Tax Preferences for Higher Education and Adult College Enrollment
}

\author{
Sara LaLumia*
}

September 20, 2010

\begin{abstract}
The federal government delivers substantial college aid through the tax code, after introducing education tax credits in 1998 and a tuition deduction in 2002. The design of the Lifetime Learning tax credit and the tuition deduction may make them particularly useful to older students. This paper investigates how these provisions have affected college attendance of individuals in their 30s and 40s. For most adults, there is no effect on college attendance. Among men whose 1998 educational attainment falls short of earlylife educational expectations, eligibility for an education tax preference is associated with a 2.5 to 3.4 percentage point increase in the probability of college attendance.
\end{abstract}

Starting in the late 1990s, the U.S. federal government has substantially expanded the amount of college aid it provides through the tax system. Two higher education tax credits, the Hope and Lifetime Learning tax credits, were introduced in 1998, and a tuition deduction was introduced in 2002. Many authors have pointed out that tax-based aid is targeted to a different group of students than is traditional federal college aid: While Pell grants are primarily for low-income individuals, tax-based aid tends to benefit the middle class. The possibility that tax-based college aid may be particularly useful to older students has been largely overlooked. In this paper I investigate the role of recent federal tax incentives for higher education on the college attendance decisions of adults in their 30s and 40s.

The Hope tax credit is designed for those who fit the profile of a traditional college student. It is available only to students who are enrolled half-time or more in the first two years of an

*Department of Economics, Williams College, Williamstown MA 01267. I am grateful for feedback from Julie Cullen, Mike Lovenheim, Joshua Miller, Lucie Schmidt, Lara Shore-Sheppard, Nick Turner, Tara Watson, Junyi Zhu, seminar participants at the University of Michigan public finance lunch, and conference participants at the Eastern Economics Association and Midwest Economics Association. Cristina Diaz-Dickson provided excellent research assistance. All errors are my own. 
undergraduate degree-granting program. In contrast, there are several reasons why the Lifetime Learning tax credit and tuition deduction may be particularly useful to older students. First, the Lifetime Learning credit and tuition deduction apply to expenses incurred during any year of higher education, including graduate school. They can be claimed for an unlimited number of years per student. Second, the Lifetime Learning credit and tuition deduction do not require recipients to be enrolled in degree-granting programs, and have no minimum hours of enrollment requirement. Data from the U.S. Department of Education (2009, Table 191) show that $74 \%$ of students ages 35 and older are enrolled part-time while only $23 \%$ of students ages 18 to 24 are enrolled part-time. Third, expenses for room and board are not covered by any of the education tax preferences. This may limit the usefulness of the tax provisions for students of traditional college age, many of whom live on campus, but is unlikely to affect the usefulness of the tax benefits for older students.

College enrollment rates among older individuals have been increasing since the 1970s, as documented by Corman (1983) and Seftor and Turner (2002). Nontraditional students now have a substantial presence in college classrooms. In 2007, students age 35 and older accounted for about $17 \%$ of all students enrolled in degree-granting institutions and about $32 \%$ of parttime students (U.S. Department of Education, 2009, Table 191). Adult college enrollment is associated with an increase in wages. Leigh and Gill (1997) find that the return to an associate's degree is of similar magnitude for younger students who have been continuously enrolled in school and for older students who return after an enrollment gap. They also find that the return to non-degree community college coursework is 8 to $10 \%$ higher for men with an enrollment gap. Jacobson, LaLonde, and Sullivan (2005) estimate the wage effects of community college enrollment using administrative data on displaced workers from the state of Washington. They find similar returns to a year of community college retraining for younger and older displaced workers, estimating a $7 \%$ increase in the long-term earnings of older men and a $10 \%$ increase for older women. In contrast, Light (1995) finds that the wage premium to delayed education, while still positive, is lower for those with longer gaps between enrollment spells. 
The information available from tax return data suggests that older students are taking advantage of education tax preferences. Public-use tax data report credits and deductions at the level of the filing unit, without identifying which member incurred any qualifying educational expenses. However, in order for a parent to claim an education tax preference on behalf of her child, the child must be a dependent. In 1998, 39.3\% of returns claiming an education credit had no exemptions for dependent children. Filers without dependent children claimed approximately $\$ 969$ million in education tax credits, $29 \%$ of all education tax credits claimed in $1998 .^{1}$ While the available evidence suggests that older individuals are claiming education tax credits, less is known about the extent to which college enrollment decisions of adults are being influenced by education tax preferences.

In this paper, I use data from the National Longitudinal Survey of Youth-1979 to estimate fixed effects regressions that explain an individual's college attendance as a function of eligibility for education tax preferences. Individuals in this sample range in age from 33 to 41 in the year that education tax credits were first available. I make use of the variation in eligibility generated by the introduction of the credits in 1998 and the tuition deduction in 2002. In my preferred specification, I instrument for eligibility by applying current-year tax law to income as of 1997, just before tax provisions for college expenses were in effect. For the full sample of men and women, I find no evidence that college attendance is affected by the tax credits or tuition deduction. I do find evidence of a positive enrollment effect among a subsample of adult men, a group I refer to as "incomplete learners." When first surveyed as teenagers in 1979, NLSY79 respondents were asked about the highest grade or year of education they expected to complete. I compare this expectation to actual educational attainment as of 1998. Among men whose 1998 educational attainment fell short of their 1979 expectations, being eligible for an education tax preference is associated with a 2.5 to 3.4 percentage point increase in the probability of college

\footnotetext{
${ }^{1}$ I calculated these values using data from the 1998 sample of individual tax returns made available by the Statistics of Income division of the IRS. The ages of filers and dependents are not reported. Thus I cannot distinguish between the returns filed by adults in their 30s or older and those filed by students of traditional college age who are no longer dependents for tax purposes. Because a filer must have positive tax liability in order to claim the non-refundable education credits, it seems plausible that older adults make up a larger share of this group.
} 
attendance. This effect is large and robust to a number of specification checks. Despite the large effect on the college attendance of male incomplete learners, I find no effect of education tax preferences on their degree completion.

\section{Background on Higher Education Tax Preferences}

The Taxpayer Relief Act of 1997 substantially expanded federal tax benefits for college expenses by introducing the Hope and Lifetime Learning tax credits. ${ }^{2}$ Tax-based college aid was further expanded in 2001 with the introduction of a tuition deduction. Table 1 shows the annual number of tax returns claiming these benefits and the dollar value claimed over the period of my analysis. In 2005, the cost of the two education tax credits was $\$ 6.1$ billion. Taxpayers deducted another $\$ 10.8$ billion of tuition and fees. With an average marginal tax rate of $22.5 \%$ in 2005, the tuition deduction cost the federal government approximately $\$ 2.4$ billion. These amounts are large relative to older tax provisions affecting higher education. The Joint Committee on Taxation (2005) estimates a cost of $\$ 0.8$ billion for the exclusion of employerprovided educational benefits and a cost of $\$ 1.4$ billion for the exclusion of scholarship income in 2005 .

While traditional college aid generally reduces recipients' out-of-pocket educational expenses, tax-based aid reimburses recipients for previously paid expenses. Credits reduce a filer's tax liability. Over all of the years I analyze, the Hope credit is equal to $100 \%$ of the first $\$ 1000$ of qualified educational expenses plus $50 \%$ of the next $\$ 1000$, with a maximum reduction in tax liability of $\$ 1500$. The Hope credit is only available for expenses incurred in the first two years of enrollment in an undergraduate degree-granting program. The student must be enrolled in school at least half time in at least one academic period during the year. For tax years 1998 through 2002, the Lifetime Learning credit was equal to $20 \%$ of the first $\$ 5000$ of expenses. Beginning in 2003, this credit has been equal to $20 \%$ of the first $\$ 10,000$ of expenses, boosting the maximum benefit from $\$ 1000$ to $\$ 2000$. The Lifetime Learning credit applies to

\footnotetext{
${ }^{2}$ Legislative details of this act are available from the Joint Committee on Taxation (1997).
} 
expenses incurred in any year of college, including graduate school. The student can be enrolled on a less than half-time basis, and need not be working towards a degree. There is no limit on the number of years in which a student can take the Lifetime Learning credit.

Both education tax credits were designed to be of greatest benefit to the middle class. The value of the credits to low-income filers is limited because the credits are nonrefundable. Any credit amount in excess of tax liability cannot be claimed. The value to high-income filers is limited by phase-outs based on adjusted gross income (AGI). When first introduced, the education credits phased out for unmarried filers with AGI between $\$ 40,000$ and $\$ 50,000$ and for joint filers with AGI between $\$ 80,000$ and $\$ 100,000$. The phase-out range has been modestly increased in subsequent years. A series of AMT patches has made the credits available to taxpayers who owe alternative minimum tax. Burman et al. (2005) document that the education tax credits do in fact primarily benefit the middle class. Households with cash income (a broad measure including taxable income as well as transfers) between $\$ 50,000$ and $\$ 100,000$ enjoyed $55.4 \%$ of total Hope benefits and $48 \%$ of Lifetime Learning benefits.

The tuition deduction was enacted as part of the Economic Growth and Tax Relief Reconciliation Act of 2001, and was first available in tax year 2002. While a credit is subtracted from tax liability, a deduction is subtracted from a filer's taxable income. The corresponding benefit to the taxpayer is equal to the amount of the deduction multiplied by the filer's marginal tax rate. The tuition deduction is an "above-the-line" deduction, meaning that it can be claimed both by itemizers and by those who take the standard deduction. In 2002 and 2003, taxpayers with AGI below $\$ 65,000$ (or below $\$ 130,000$ if filing a joint return) could deduct up to $\$ 3000$ in qualified educational expenses. In 2004 and 2005, taxpayers in the same AGI category could deduct up to $\$ 4000$, while taxpayers with AGI between $\$ 65,000$ and $\$ 80,000$ (or between $\$ 130,000$ and $\$ 160,000$ if filing a joint return) could deduct up to $\$ 2000$. Burman et al. (2005) show that households with cash income between $\$ 50,000$ and $\$ 100,000$ received $27.1 \%$ of benefits from the tuition deduction, while households with cash income between $\$ 100,000$ and $\$ 200,000$ received $51.8 \%$ of its benefits in 2005 . 
For all three of these tax preferences, qualified educational expenses include tuition and fees required for enrollment at a college, university, or vocational school. Payments for room and board, student health insurance, books, or student activities are not included. Expenses that are paid with a loan can be claimed but expenses that are paid with a tax-free scholarship or grant cannot be claimed. Qualified expenses can be incurred on behalf of the primary tax filer, the filer's spouse, or the filer's dependent child. ${ }^{3}$ The credits and the tuition deduction are not available to married taxpayers who file separately.

Qualified educational expenses may be incurred for multiple individuals within a household in a given year. For example, a parent may take college classes at the same time that her dependent child is in college. Hope credits can be claimed for multiple students per return, with the maximum dollar value defined per student rather than per return. Thus, if neither the parent nor the child has completed more than two years of college, the household can claim two Hope credits, each worth up to $\$ 1500$. The Lifetime Learning credit can also be claimed for multiple students per return, but the combined value of all Lifetime Learning credits claimed on a given return is capped at $\$ 1000$ in $1998-2002$ and at $\$ 2000$ in 2003-2005. Similarly, the maximum amount of the tuition deduction is defined per return rather than per student. A taxpayer cannot claim more than one tax preference for the same student in a given year.

Long (2004) demonstrates that take-up of the Hope and Lifetime Learning credits over their first three years fell short of initial predictions by the U.S. Department of Education. By 2000, spending on the tax credits was only about half of what the Department of Education had predicted. Using data from the 1999-2000 National Postsecondary Student Aid Study, Long estimates that $27 \%$ to $29 \%$ of all eligible students claimed an education tax credit. The takeup rate is somewhat higher among older students: $32 \%$ to $34 \%$ among eligible nontraditional undergraduates and 35\% to 38\% among eligible graduate and professional students.

\footnotetext{
${ }^{3}$ When the qualifying expenses are for a child's education, the parent must claim a dependent exemption for the child in order to claim the corresponding credit or tuition deduction. In the case of a credit, any expenses paid directly by the dependent child are treated as having been paid by the parent. In the case of the tuition deduction, if the dependent child pays expenses directly then neither the parent nor the child can deduct those expenses.
} 
The Taxpayer Relief Act of 1997 included other provisions related to higher education, all described by the Joint Committee on Taxation (1997). It introduced an above-the-line deduction for interest paid on a student loan. This deduction phases out at middle-income AGI levels, and most filers who are income-eligible for an education tax credit or tuition deduction are also income-eligible for the student loan interest deduction. ${ }^{4}$ By reducing the net present value of college costs, the interest deduction may increase college enrollment. It is possible that some of the college attendance response I attribute to education tax credits and the tuition deduction is actually explained by the student loan interest deduction. However, it is currently a much smaller expenditure than the education tax credits or tuition deduction, costing the federal government only $\$ 0.8$ billion in 2005. The 1997 law also introduced education IRAs, later known as Coverdell savings accounts. Coverdell savings accounts will not affect the college attendance of members of my sample, as contributions must be for children under age 18 .

Because the delivery of substantial college aid through the tax code is a recent phenomenon, there is only a small body of literature on the effects of these tax preferences. Just prior to the passage of the education tax credits, Cronin (1997) predicted that the proposed Hope credit would increase college enrollment by between 150,000 and 1.4 million students by 2002. Hoxby (1998) predicted that the Hope and Lifetime Learning credits would have only small effects on human capital investment and would instead generate tuition inflation, particularly at colleges with initially low tuition and relatively immobile student bodies. Long (2004) documents the effects of the credits over their first three years. Using October Current Population Survey (CPS) data, Long finds no evidence that the credits changed enrollment either for those of traditional college age, 18-24, or for those ages 25-40. Because income is available only as a categorical variable and is topcoded at $\$ 75,000$ in the October CPS, eligibility for the credits is likely measured with error. Thus attenuation may be biasing Long's estimates towards zero and there is a good case for estimating the education credit enrollment effects using a data set with more precise income information. Turner (2010a) estimates the effects of the tax credits and

\footnotetext{
${ }^{4}$ In my sample, $88 \%$ of those who are eligible for an education tax credit or tuition deduction would also qualify for the student loan interest deduction.
} 
tuition deduction on the enrollment decisions of 18- and 19-year-olds using data from the 1996 and 2001 waves of the Survey of Income and Program Participation. He finds that the programs have increased college enrollment rates of 18- and 19-year-olds by 2.2 percentage points, or 6.7 percent.

This paper is related to the large literature investigating the relationship between college costs and enrollment, summarized in Leslie and Brinkman (1987), Heller (1997), and Dynarski (2002). Nearly all of this work has focused on individuals of traditional college age, 18 to 24. One exception is a paper by Seftor and Turner (2002), which estimates the effects of Pell grants on the college enrollment of household heads, ages 22 to 35 . The Pell's 1973 introduction is associated with a significant increase in college enrollment of approximately 1.3 percentage points. Tightening of the program's definition of an independent student in 1986 is associated with a 3.9 to 4.2 percentage point decline in enrollment. These responses are larger than what is typically estimated for recent high school graduates. Seftor and Turner speculate that older students may be more sensitive to federal financial aid because they find the application process less daunting, because they are more credit constrained, or because they typically attend colleges at which the undoing of federal aid through changes in institutional aid is unlikely.

\section{Estimation Strategy}

I rely on statutory variation in the availability and generosity of education-related tax preferences in order to estimate their enrollment effects. This variation is generated by the introduction of the two credits in 1998, the introduction of the tuition deduction in 2002, and small changes in the income eligibility for each. I use panel data to estimate fixed effects models of the form:

$$
\text { College }_{i t}=\beta \cdot \text { Eligible }_{i t}+\lambda \cdot \text { Time }+\gamma \cdot X_{i t}+\delta_{i}+\epsilon_{i t} .
$$

The dependent variable is a measure of college attendance during year $t$. The explanatory variable of greatest interest is Eligible, equal to one if a respondent qualifies for any benefit 
from the Hope credit, Lifetime Learning credit, or tuition deduction during year $t$. I include a linear time trend and a vector $X$ of time-varying demographic controls. The individual-specific fixed effect is $\delta_{i}$.

The estimation of fixed effects models is useful in a context where eligibility is a function of income. Individuals earning enough to benefit from non-refundable credits may differ in systematic ways from individuals made ineligible by their low earnings, and may differ in other ways from those with income above the eligibility cutoff. If unobserved determinants of tax preference eligibility are also correlated with college attendance, cross-sectional estimates will be biased. The number of characteristics potentially correlated with both income and college attendance is large, including motivation and taste for school. If these characteristics are constant over time, fixed effects estimation will remove them from the error term. In the results section I show estimates from pooled cross-sectional analysis for the sake of comparison, but my preferred specification includes fixed effects.

An individual's eligibility for a tax preference in a particular year is a function of the prevailing tax law and his income in that year. The tax law is exogenous to the individual's college attendance decision, but the individual's current income is not. For adults in their 30 s and 40s, the decision to attend college plausibly involves some sacrifice of labor market time and hence a reduction in income. In order to address this endogeneity, I instrument for Eligible. My instrument predicts eligibility in year $t$ using the tax law for year $t$ and inflationadjusted individual income from 1997, just before the education tax credits were in effect. ${ }^{5}$ This methodology implicitly holds labor supply constant at 1997 levels. While this approach is quite useful for identification, there is a drawback. This analysis cannot explain how individuals with

\footnotetext{
${ }^{5}$ Using 1997 income to predict later eligibility would be problematic if taxpayers strategically altered their 1997 income in response to the passage of the education tax credits. The Taxpayer Relief Act was passed on June 26, 1997. It specified that the Hope credit would apply to expenses paid after December 31, 1997 and that the Lifetime Learning credit would apply to expenses paid after June 30, 1998. Income from tax year 1998 would be used to determine whether an individual could claim the credits in 1998. Even if taxpayers eventually alter their income in order to qualify, perhaps by adjusting labor supply, there would be no reason to do so before 1998. It is possible that passage of the law altered other behaviors. For example, savings behavior may have changed if expectations of future college enrollment increased. The law specified that any expenses for education provided before the tax credits became available would not be covered. Thus, the law did not create an incentive to delay making payments on educational expenses incurred in the second half of 1997.
} 
substantial negative income shocks, such as job loss, may be using education tax preferences.

In addition to the key eligibility variable, I include a number of time-varying demographic controls. I control for marital status, because the possibility of relying on a spouse's income may make it easier for married adults to return to college. The presence of children in the household may reduce the time available for college, particularly for women, and so I include a variable measuring the number of children in the household and a dummy variable indicating whether there are any children under age six. I include an indicator for living in an urban area as a measure of physical access to college. Jepsen and Montgomery (2009) show that adult community college enrollment rates are quite sensitive to distance. In simulations for their sample of Baltimore-area adults, an across-the-board one-mile increase in distance to the nearest community college would reduce the probability of enrollment by 3 to $5 \%$.

The same tax reforms that introduced the education tax credits and tuition deduction also lowered marginal tax rates for many filers. It is plausible that a reduction in the marginal tax rate will influence adult college enrollment, although the sign of the effect is uncertain. A lower tax rate increases the net return to work, and hence increases the opportunity cost of college attendance. On the other hand, higher after-tax income may lead to greater consumption of education. Because an individual's marginal tax rate is a function of her income, I control for an individual's predicted rather than actual federal marginal tax rate. I predict this rate for year $t$ by applying year $t$ tax law to 1997 income, adjusted for inflation.

In some specifications, I include AGI and labor supply measures in $X$. Interpreting the coefficients on these variables is difficult, because they are likely endogenous to college enrollment. Belley and Lochner (2007) show that, for individuals of traditional college age, family income has become a more important determinant of college enrollment in recent years. While the relationship may be different for older adults who are not relying on parental resources, income is likely still an important predictor of college attendance. For adults with several years of work experience, the opportunity costs of college in terms of forgone earnings may be more important than the sticker price of college. I hypothesize that stronger attachment to the labor 
force, as measured by weeks worked in the previous calendar year, will be associated with lower probability of college attendance. Betts and McFarland (1995) show that community college enrollment is quite sensitive to local unemployment rates. To investigate whether spells of unemployment are associated with increased college attendance, I include an indicator for having any weeks of unemployment during the calendar year prior to the interview.

I estimate Equation 1 separately for men and women. This is a sensible strategy because many of the control variables, such as the presence of young children in the household, affect the behaviors of men and women differently, and because men's and women's college graduation rates have been trending differently for decades. ${ }^{6}$ Standard errors are clustered at the individual level.

\section{Data}

\subsection{National Longitudinal Survey of Youth-1979}

I use data from the 1998-2006 rounds of the NLSY79. The NLSY79, administered by the Bureau of Labor Statistics, has followed a group of 12,686 respondents ages 14-21 as of December 1978. The survey has documented the transitions of these individuals through school and into the workforce, with follow-up surveys conducted annually until 1994 and in even-numbered years since then. Attrition has been relatively low, with 8399 respondents participating in the survey in 1998. The longitudinal nature of this survey and its detailed income and college enrollment questions make it well suited to my analysis.

The NLSY79 provides more detailed information on educational enrollment and attainment than the October CPS, which has previously been used by Long (2004) and Seftor and Turner (2002) to study college enrollment decisions. As in the CPS, respondents are asked about their current enrollment status at the time of interview. In addition, each survey round includes

\footnotetext{
${ }^{6}$ Goldin, Katz, and Kuziemko (2006) show that the ratio of male to female college graduation rates has been falling since the 1950s, and that women have had higher graduation rates since about 1980.
} 
retrospective questions on the beginning and ending dates of enrollment spells at up to three colleges attended since the last interview. The dependent variable that I focus on in my analysis is an indicator for any college enrollment in the tax year prior to the interview (the period over which tax preference eligibility is measured).

I restrict my sample to individuals who had completed at least grade 12 by the time of the 1998 interview. Tax preferences for college expenses are not designed, and are unlikely, to affect the behavior of those with less than a high school degree. This restriction eliminates 1015 observations, resulting in a sample of 7384 individuals, 3832 women and 3552 men. $^{7}$ I use an unbalanced panel: All of these individuals are observed in the 1998 survey round, but each can have from zero to four observations over the next four survey rounds. NLSY79 participation rates are quite high, and nearly $80 \%$ of the respondents in my sample are present in all five rounds. For each year, I drop a handful of observations for whom missing income information prevents calculation of tax liability. The regressions presented below include 17,573 person-year observations for women and 15,942 person-year observations for men.

Weighted summary statistics for this sample are shown in Table 2. These statistics reflect the distinctive nature of the NLSY79. Over the time period considered here, individuals in the sample range in age from 33 (the youngest respondents at the time of the 1998 interview) to 50 (the oldest respondents at the time of the 2006 interview). The mean age of all person-year observations is 41. About two-thirds of them are married and most have children. Median adjusted gross income, in real 2005 dollars, is approximately $\$ 55,000 .^{8}$

College attendance is relatively rare for my sample. Table 2 shows that across all person-

\footnotetext{
${ }^{7}$ Completing twelve years of school does not always correspond to obtaining a high school diploma. Some individuals may complete grade 12 but not satisfy a requirement for graduation. Others may obtain a diploma or GED after completing fewer than twelve years of schooling. I choose to define my sample in terms of grades completed rather than highest degree obtained because I can then take advantage of a variable constructed by NLSY staff that represents extensive cross-round comparison and cleaning. Every respondent who participated in the 1998 survey has been assigned a non-missing value for highest grade completed. If I compile information across surveys on highest degree obtained as of 1998, this variable is missing for 300 of the 7384 individuals in my sample. I have investigated the sensitivity of my results to a tighter sample definition. If I drop the 349 individuals with twelve years of completed schooling but who have obtained less than a high school degree or GED, as well as the 300 with missing degree information, my results are qualitatively unchanged.

${ }^{8}$ Census data in DeNavas-Walt et al. (2006) show that median household income in 2005 was $\$ 58,084$ among households headed by a person age 35 to 44 .
} 
year observations, only $6.7 \%$ of women and $3.4 \%$ of men attend college. Measured at the person level, $18.4 \%$ of women and $9.9 \%$ of men attend college in at least one of the five years included in my analysis. Figure 1 shows how this behavior has changed over time for various groups. This figure illustrates that college attendance rates are consistently higher for women than for men, and are generally falling as the sample ages. I divide respondents into those who are never eligible for an education tax preference and those whose 1997 income would make them eligible for an education tax preference in at least one subsequent year. This division of the sample parallels the construction of my instrument. Respondents in middle-income households fall into the eligible group, while those with income too low to benefit from a nonrefundable credit or with income above the cutoff fall into the ineligible group. In 1997, the education tax credits and tuition deduction were not yet available, but for purposes of the figure I count a 1997 observation as income-eligible if the application of 1999 tax law to 1997 income would qualify that respondent for an education tax credit. If education tax credits boost adult college enrollment, I would expect the college attendance rate among eligible individuals to increase relative to the college attendance rate among ineligibles after 1997. If the tuition deduction boosts adult college enrollment, there should be a further widening of the college attendance gap between eligible and ineligible individuals in 2003 and 2005. There is no evidence of such a pattern among women. Among men, the college attendance of eligible individuals actually falls relative to the college attendance of ineligible individuals in the first two years in which education credits are available. The relative rate of college attendance then increases in the next two years, in which the tuition deduction is also available. Overall, this time series evidence offers little support for the hypothesis that education tax preferences have increased adult college attendance.

Among those in my sample who do attend college, the majority enroll part-time at a 4-year college. About $64 \%$ of these college students attend a 4 -year college and about $62 \%$ attend part-time. About $80 \%$ of the college students in my sample also worked 26 weeks or more during the year. These patterns are similar for men and women. 
When first interviewed in 1979, respondents were asked how many years of education they expected to eventually complete. The mean expectation in my sample is 14 years, with $36 \%$ expecting to complete 12 years, $19 \%$ expecting to complete 13 to 15 years, and $28 \%$ expecting to complete 16 years. Table 3 compares educational expectations and the actual number of years of education completed as of the 1998 interview. About half of male and female respondents attain their expected level of education. About one third had completed fewer years of education by 1998 than they had expected to. I refer to this group as "incomplete learners."

Table 4 compares incomplete learners and others on a number of observable characteristics. The incomplete learners were more optimistic in 1979, on average reporting that they expected to complete 15.7 years of education. The remainder of the sample expected to complete 13.4 years of education. By the time of the 1998 survey, the incomplete learners had completed an average of 13.3 years of education while the rest of the sample had completed 14.1 years of education. Educational expectations were collected at one point in time, 1979, from respondents who ranged in age from 14 to 21 . It seems plausible that those on the older end of this age range might be more accurate in their predictions, and less likely to appear in the incomplete learner group. Table 4 establishes, however, that being in the incomplete learner group is not merely a proxy for being young. The average age at first interview is essentially the same for incomplete learners and for others. About $75 \%$ of the incomplete learner group is white while $83 \%$ of the remainder of the sample is white. The bottom panel of Table 4 shows summary statistics at the respondent-year level. Among women, incomplete learners are somewhat less likely to have a young child in the home, have lower mean and median AGI, and are more likely to attend college at some point over the 1997-2005 period. Among men, the two groups are fairly similar on observable characteristics. Incomplete learners are somewhat more likely to attend college during the time of my analysis. Among all the college students in my sample, incomplete learners are less likely to be attending a 4-year college (55\% vs. $70 \%$ ) and about equally likely to be attending college part-time (61\% vs. $63 \%)$. 


\subsection{Estimating Tax Preference Eligibility}

The NLSY79 includes detailed income information, with income questions in a given round corresponding to the previous calendar year. This information is critical for identifying which individuals are eligible for the education tax preferences. Because I use data from the 1998 to 2006 survey rounds, I have income data for odd-numbered years from 1997 to 2005. Respondents report the amounts of income received from a variety of sources. Although the NLSY79 includes a constructed summary measure of income, total net family income, this measure is inappropriate for determining eligibility for the education tax credits and deduction as it includes many types of non-taxable transfer income. Instead I aggregate the taxable forms of income and use the NBER TaxSim program to estimate each respondent's AGI, tax liability, and marginal tax rate. ${ }^{9}$ These TaxSim calculations are for federal taxes only, as state of residence is not available in the public-use NLSY79 data. The lack of state tax estimates is not particularly problematic in this context, as eligibility depends only on federal tax parameters. The taxable income elements I use include wage income, income after expenses from any farms or businesses, military wages, scholarship and fellowship income, unemployment compensation, income from Social Security and disability insurance (beginning in 2001), and an "other income" category. This category includes interest, dividends, rental income, royalties, and annuities. I include the income of the respondent's spouse or partner for those who report having filed a joint return. I estimate tax parameters for all respondents, even those who say that they did not file a tax return.

The NLSY79 does not ask respondents if they itemize deductions or take the standard deduction. Aggregate tax statistics for 1997 show that $30 \%$ of all returns and $49 \%$ of joint returns had itemized deductions. Itemizing reduces a filer's taxable income and tax liability but has no effect on AGI. If a filer has a positive tax liability with the standard deduction but zero tax liability with itemized deductions, he cannot benefit from the nonrefundable education tax credits when he itemizes. Thus, failing to account for itemizing would cause me to overestimate

\footnotetext{
${ }^{9}$ For a description of the TaxSim program, see Feenberg and Coutts (1993).
} 
the number of respondents who are eligible for an education tax benefit. Lacking direct evidence on who itemizes, I use homeowner status to proxy for itemizing. Aggregate statistics from the IRS show that expenses associated with owning a home (real estate taxes and mortgage interest) accounted for half of the dollar value of all itemized deductions claimed in 1997. Among those who itemized, $88 \%$ deducted real estate taxes and $83 \%$ deducted home mortgage interest. The only type of deduction to be claimed more often by itemizers is charitable giving, reported by $89 \%$ of itemizers. In three out of the five survey rounds I use, respondents are asked if they own or are making payments on their homes. ${ }^{10}$ I use homeownership in 1998 to proxy for itemizing in 1997, homeownership in 2000 to proxy for itemizing in 1999 and 2001, and homeownership in 2004 to proxy for itemizing in 2003 and 2005. I assign each imputed itemizer a dollar value of itemized deductions equal to the average, from aggregate IRS statistics, for his filing status and AGI category. ${ }^{11}$

I use the TaxSim calculations of federal AGI, tax liability, and marginal tax rate to estimate the maximum dollar amount of education tax preferences that a filer could receive in a given year. I estimate the value of the Hope credit, Lifetime Learning credit, and deduction separately, adjusting for the phase-out of benefits at higher levels of AGI and the limited applicability of benefits to filers with low tax liability. Because the Hope credit is restricted to expenses incurred in the first two years of college, I set the maximum value of the Hope benefit equal to zero for respondents who have completed two or more years of college by the time of the interview. ${ }^{12}$ If eligible for a positive benefit from more than one tax preference, I assume the filer chooses the most valuable benefit, as the tax law allows only one of these three tax preferences to be claimed per student in a given year. ${ }^{13}$ None of the education tax preferences was available in

\footnotetext{
${ }^{10}$ This question is part of the asset section, which is not included in the 2002 and 2006 rounds.

${ }^{11}$ The average deduction value per itemizer, for each of 14 AGI categories and three filing status categories, comes from the Internal Revenue Service (2000).

${ }^{12}$ Hoxby (1998) points out that there is virtually no way to enforce this rule in the first two years of the Hope credit's existence, as the IRS must rely on individuals' self-reports of previous college experience. Ignoring prior years of college experience in my calculation of tax benefits has almost no effect on my results. An individual who is eligible for a non-zero benefit from the Hope credit is also eligible for a non-zero benefit from the Lifetime Learning tax credit, although the dollar amount of the benefit will differ.

${ }^{13}$ Evidence from GAO (2008) and Turner (2010b) indicates that between $20 \%$ and $28 \%$ of taxpayers choose suboptimally from among the available tax benefits. My focus on an eligibility dummy variable rather than the
} 
tax year 1997, so the benefit amount is equal to zero for all 1997 observations.

Figure 2 plots the maximum dollar value of education tax preference available to respondents. Only respondents with AGI less than $\$ 200,000$ are included, as all taxpayers with higher incomes are ineligible for the education tax preferences. Values for 1999 are shown in the top panel. This panel shows a concentration of respondents eligible for the maximum Hope amount of $\$ 1500$. About $43 \%$ of those who are eligible for any education tax benefit in 1999 are eligible for the full $\$ 1500$. Two downward-sloping lines, one in the $\$ 40,000$ to $\$ 50,000$ and the other in the $\$ 80,000$ to $\$ 100,000$ AGI range, represent respondents subject to the Hope's phase-out provisions for unmarried and married filers. There is also a concentration of respondents eligible for the maximum Lifetime Learning amount of $\$ 1000$. These individuals are prevented from claiming the more generous Hope credit because they have already completed two or more years of college. About 29\% of those eligible for any education tax benefit in 1999 are eligible for $\$ 1000$. Two additional downward-sloping lines, starting at a tax benefit of $\$ 1000$, represent respondents subject to the phase-out of the Lifetime Learning credit. Respondents with positive tax benefits of amounts other than $\$ 1000$ or $\$ 1500$ are either subject to the phase-out provisions or have low tax liability which caps their benefit from nonrefundable credits.

Values for 2005 are shown in the bottom panel of Figure 2. While distinct Hope and Lifetime Learning populations are evident in the 1999 figure, this is not the case in 2005. Statutory changes had increased the maximum Lifetime Learning credit amount to $\$ 2000$, and the less restrictive Lifetime Learning credit now offers the larger maximum possible benefit. About 43\% of those eligible for any education tax benefit in 2005 are eligible for the full $\$ 2000$. Respondents subject to the phase out of the credit are visible in AGI ranges of $\$ 43,000$ to $\$ 53,000$ (unmarried filers) and $\$ 87,000$ to $\$ 107,000$ (joint filers). The newly available tuition deduction results in tax benefits for higher-AGI respondents. The clusters of benefit values visible in the figure reflect tax brackets. For example, filers who can deduct $\$ 4000$ of educational expenses and who are in the $25 \%$ tax bracket receive a benefit of $\$ 1000$.

dollar amount of benefit makes this less of a concern in my analysis. 
I define an eligibility dummy variable equal to one if the maximum benefit amount is greater than zero. This is the key regressor in my analysis, although I also investigate the sensitivity of my results to measuring eligibility in dollar terms. ${ }^{14}$ Table 2 indicates that about $50 \%$ of person-year observations are eligible for an education tax preference. This masks heterogeneity across years. No one is eligible in 1997, because none of the three tax provisions I consider was yet available. Roughly 60\% of respondents are eligible in 1999 and 2001, and the introduction of the tuition deduction boosts the eligible share to approximately $70 \%$ by 2005 .

To construct my instruments, I estimate a second set of tax parameters. I hold household composition fixed as it was in 1997, index the taxable components of income reported in 1997 for inflation, and apply later-year tax law in two steps. First, I use TaxSim to compute the hypothetical federal AGI, tax liability, and marginal tax rate corresponding to inflation-adjusted 1997 income. I then use the TaxSim output and later-year education tax credit and tuition deduction rules to compute a respondent's predicted maximum value of education tax preferences. If this predicted dollar value is greater than zero, the predicted eligibility dummy is equal to one. This method of constructing an instrument for a tax parameter has been used previously, for example by Carroll et al. (2000).

Estimating a fixed effects specification requires that individuals move in or out of eligibility over time. Individuals who are never eligible or always eligible for an education tax preference do not contribute to identification. Using data that span the introduction of the tax preferences is helpful on this dimension, ensuring that no individual is always eligible. Among those who appear in all five rounds of the survey, about $18 \%$ are never eligible. In constructing my instrument, I isolate the change in eligibility resulting from changes in tax law - the introduction of the credits in 1998, the introduction of the tuition deduction in 2002, and small changes in the income eligibility thresholds. These changes are plausibly exogenous to individual college

\footnotetext{
${ }^{14}$ The dollar value that I compute is the maximum benefit a person could receive, based on his AGI and tax liability. This will overstate the benefit of tax preferences to individuals with low levels of college spending, either because they attend low-tuition colleges or because they cover most of their tuition expenses with tax-free scholarships or grants. Aggregate tax return data published in Table 3.3 of the Statistics of Income Individual Complete Report show that the average credit amount on returns claiming either the Hope or Lifetime Learning credit in 2005 is $\$ 867$, well below the maximum possible value.
} 
attendance and labor supply decisions. The number of respondents with zero years of predicted eligibility is substantially higher than the number with zero years of actual eligibility, accounting for about $35 \%$ of the sample. It is still the case, however, that a majority of respondents experience a change in predicted eligibility.

\section{Results}

Tables 5 and 6 present estimates of the effect of eligibility for the Hope credit, Lifetime Learning credit, or tuition deduction on college attendance. The dependent variable is a dummy equal to one if the respondent reported having attended college at any point in the year prior to the survey, the same period over which eligibility is measured. Table 5 reports results for women and Table 6 reports results for men.

OLS estimates are shown in column 1. The coefficient on Eligible is positive for both women and men, and statistically significant at the $1 \%$ level for men. The coefficient for men suggests that being eligible for an education tax preference is associated with a 1.0 percentage point increase in the probability of college attendance. This result should be interpreted with skepticism, though, as there may be unobserved individual characteristics that affect both college attendance and the likelihood of being income-eligible for an education tax preference. Signing the direction of the bias is difficult, because eligibility for a tax preference is not a linear function of income. Low-income filers are ineligible because they have little tax liability to offset with a credit, while high-income filers are ineligible because of the phase-out rules.

The fixed effects specification shown in column 2 removes from the error term any unobserved individual-specific characteristics that are constant over time. This results in a smaller point estimate of the Eligible coefficient for men and a negative point estimate for women. The potential problem with these estimates is that Eligible in year $t$ is calculated as a function of year $t$ income, and year $t$ income plausibly depends on college enrollment in year $t$. Again, it is difficult to sign the bias introduced by this reverse causality. Suppose that for an adult in his or 
her late 30s, the decision to attend college involves reducing labor supply and thus is associated with lower income. For an individual initially earning too much to qualify for an education tax preference, the decline in earnings may make him newly eligible. In this case, there will be a spurious positive correlation between eligibility and college attendance. On the other hand, a decline in earnings associated with college enrollment could move an individual from the eligible range to having too little tax liability to benefit from a nonrefundable credit. In this case, there will be a spurious negative correlation between eligibility and college attendance.

To address the endogeneity of tax preference eligibility, I instrument for Eligible using information on the tax code in year $t$ and an individual's income in 1997. The first-stage results show a very strong relationship between the instrument (eligibility predicted by applying lateryear tax law to inflation-adjusted 1997 income) and the endogenous eligibility dummy. For women, the first-stage coefficient on the instrument is 0.498 , with a t statistic of 49 . For men, the coefficient on the instrument is 0.523 , with a t statistic of 51. Second-stage results are shown in column 3 of Tables 5 and $6 .{ }^{15}$ In this preferred specification, there is no evidence that tax preferences affect the college attendance of adults. For both women and men, the coefficients on Eligible are not statistically different from zero. In a specification not shown in the table, I have pooled together men and women. For this combined sample, the eligibility coefficient is near zero and insignificant.

The effects of other covariates are generally consistent across specifications. There is a negative time trend for both men and women, reflecting the fact that college attendance declines with age. Being married and having any child under the age of six significantly reduce a woman's probability of attending college, but have essentially no effect on men's college attendance. There is no significant relationship between a respondent's marginal tax rate and college attendance.

In column 4, I add a set of potentially endogenous control variables: AGI (measured in tens of thousands) and its square, the number of weeks worked last year, and an indicator for

\footnotetext{
${ }^{15}$ The sample size is somewhat smaller here because individuals with only one year of data are not used in this specification.
} 
any weeks of unemployment last year. Reassuringly, adding these controls generates very little change in the key Eligible coefficient. The pattern of coefficients on AGI and AGI squared indicates that college attendance is declining with income over much of the income range, only becoming positive at an AGI of around $\$ 500,000$. While the usual finding is that college attendance increases with income over most of the income range, evidence of the opposite pattern here is not particularly troubling. It is quite plausible that the relationship between enrollment rates of dependent 18-year-olds and parental income is strongly positive while the relationship between the enrollment rates of adults and household income is generally negative. Stronger attachment to the labor force, as measured by the number of weeks worked in the past year, is associated with a lower probability of college attendance for women. Experiencing any weeks of unemployment in the past year is not significantly correlated with college attendance.

The last two columns of Tables 5 and 6 show fixed effects IV regression results for the subsample of incomplete learners, those whose actual 1998 educational attainment falls below their 1979 expectations. The first-stage regressions for incomplete learners show that the instrument is a strong predictor of eligibility. For female incomplete learners the coefficient on the instrument is 0.507 with a t statistic of 32 and for male incomplete learners the coefficient on the instrument is 0.496 with a t statistic of 31 . In the second stage, the coefficient on eligibility is insignificant for women and positive and significant for men. Among the sample of male incomplete learners, being eligible for a tax benefit is associated with a 3.4 percentage point increase in the probability of college attendance. ${ }^{16}$ The coefficients on other control variables are generally similar to estimates for the full sample. Adding controls for AGI, weeks worked, and unemployment in column 6 does not change the main result: Eligibility for an education tax credit has a large positive effect on the probability of college attendance among male incomplete learners. If I estimate a single regression pooling together male and female incomplete learners, the Eligible coefficient indicates a 2.2 percentage point college attendance response,

\footnotetext{
${ }^{16}$ OLS and fixed effects specifications also indicate a positive and significant, although smaller, response among male incomplete learners. The point estimates from these regressions indicate a 1.7 percentage point increase in the probability of college attendance. For female incomplete learners, an OLS regression indicates a positive enrollment response but the fixed effects specification suggests a near-zero response.
} 
significant at the $10 \%$ level.

Not surprisingly, individuals who are classified as incomplete learners have relatively low levels of education as of the 1998 survey. It is possible that the relevant distinction between incomplete learners and others is actually the level of education attained as of 1998, rather than how this attainment compares to 1979 expectations. To investigate this possibility, I restrict my sample to individuals who had completed between 12 and 15 years of schooling as of the 1998 interview. With this restriction in place, the Eligible coefficient from the fixed effects IV specification is 0.005 with a standard error of 0.014 for women. For men, the coefficient is 0.018 with a standard error of 0.008 . Next, I restrict my sample to those whose highest degree obtained as of 1998 is at least a high school diploma (or GED) and something less than a bachelor's degree. In this case, the fixed effects IV specification yields an Eligible coefficient of $0.001(0.015)$ for women and $0.012(0.008)$ for men. These results suggest that unrealized educational expectations, distinct from low initial levels of education, do in fact play a role in determining the responsiveness to education tax preferences.

A 3.4 percentage point increase in the probability of college attendance is a very large effect, given that college attendance is reported for only $4 \%$ of person-year observations of male incomplete learners. This estimate is also large relative to other estimates from the college enrollment literature. Turner (2010a) finds that the Hope credit, Lifetime Learning credit, and tuition deduction have increased full-time college enrollment of 18- and 19-year-olds by 2.2 percentage points, relative to a baseline enrollment rate of 30\%. Seftor and Turner (2002) estimate that eligibility for the Pell grant over its first four full years of existence, 1974 to 1977 , increased the probability of college attendance among household heads ages 22 to 35 by about 1.5 percentage points. Seftor and Turner's results for women are quite robust to the definition of the treatment group and to alternative sample restrictions, but the results for men vary. When all college enrollment is considered, instead of undergraduate enrollment only, the point estimate for men suggests that Pell eligibility is associated with a 2.7 to 2.9 percentage point increase in college attendance. In comparing the magnitude of these estimates to mine, it is 
important to note that the typical Pell grant of the 1974-1977 period is more generous, in real terms, than the average value of the education tax preferences. Cook and King (2007) report the dollar amount of the average Pell grant in each year since its inception. Averaged over 1974 to 1977, the typical Pell grant amount is approximately $\$ 2575$, expressed in real 2005 dollars. In contrast, the average credit amount on returns claiming either the Hope or Lifetime Learning credit in 2005 is $\$ 867$. Because my baseline estimate for male incomplete learners is surprisingly large, it is important to investigate the robustness of this result.

\subsection{Robustness Checks}

In this section I vary the assumptions made about tax filing behavior, I consider alternative sample definitions, and I replace the eligibility dummy variable with a dollar value measure. The finding of a large college attendance response among male incomplete learners and an insignificant response among other groups is robust to these changes.

To this point, I have computed the potential tax benefit in the same way for all respondents, regardless of whether they reported filing a tax return. In practice, of course, it is necessary to file in order to receive any tax benefit. I estimate an alternative specification in which I treat all self-reported non-filers as ineligible for education tax preferences. The corresponding fixed effects IV results are shown in row B of Table 7 . Only among the male incomplete learners is there evidence that the education tax preferences increase college attendance. The point estimate is somewhat smaller than in the baseline, suggesting that tax preference eligibility is associated with a 2.8 percentage point increase in the probability of college attendance. As a second alternative, I drop non-filers and estimate regressions only for those who report having filed a tax return. This reduces sample sizes by about 15\%. The results of the corresponding fixed effects IV regressions are shown in row $\mathrm{C}$ of Table 7. Dropping non-filers generates results that are quite similar to the baseline.

Taken together, the first three rows of Table 7 indicate that the finding of a large college attendance response among male incomplete learners and no attendance response among other 
groups is relatively stable to the way in which I treat reported non-filers. While this is reassuring, there are two reasons why I prefer the baseline specification. First, reports of non-filing may be inaccurate. The non-filing rate is higher in the NLSY79 than in the population, rising from $11.5 \%$ for tax year 1997 to an unrealistically high $25.2 \%$ for tax year 2005. Many respondents who report that they did not file a tax return simultaneously report income well above the filing threshold. This issue becomes more striking in later years. For tax year 1997, 59\% of those who say they do not file appear to be legitimate non-filers, with AGI below the filing threshold. ${ }^{17}$ By 2005, only $23 \%$ of those who say they do not file have AGI below the filing threshold. Second, it is possible that the decision to file is influenced by the set of tax preferences available. Computing the potential tax benefit in the same way regardless of reported filing status, as I do in the baseline, ensures that the key regressor is a plausibly exogenous measure of eligibility.

My baseline specification assumes that homeowners itemize deductions. In row D of Table 7 I instead assume that all respondents take the standard deduction. In this specification, the eligibility coefficient for male incomplete learners falls to 2.5 percentage points, significant at the $10 \%$ level. The eligibility coefficient for female incomplete learners is nearly as large in magnitude, but is imprecisely estimated.

The research design in this paper assumes that when education tax preferences become available to middle-income individuals, patterns of college enrollment among the ineligibles are the same as they would have been absent the introduction of the tax preferences. This assumption will be violated if other policy changes are simultaneously influencing the college enrollment patterns among ineligibles. The group of individuals ineligible for an education tax preference contains two distinct subsets. There are low-income individuals with too little income to benefit from a non-refundable credit, and high-income individuals with AGI above the eligibility thresholds. The college attendance of those in the low-income control group may have been affected by welfare reform of the mid-1990s. This reform made welfare receipt

\footnotetext{
${ }^{17}$ In 1997 , the filing threshold is $\$ 6800$ for single filers, $\$ 12200$ for joint filers, and $\$ 8700$ for head of household filers. These amounts are adjusted annually for inflation.
} 
contingent on participation in a work-related activity. In some states, attending college satisfies the work requirements for welfare. If changes in state welfare rules caused college enrollment of low-income individuals to increase (decrease) over my sample period, my estimates of the college enrollment effects of education tax preferences, particularly for women, will be biased downwards (upwards). ${ }^{18}$ To address this issue, I drop those in the low-income control group and re-estimate college attendance regressions. The corresponding results are shown in row E of Table 7. Relative to the baseline, this change has very little effect on the results. Only among male incomplete learners is there evidence that education tax preferences have affected college attendance.

There is not an obvious counterpoint policy change that would have affected the college attendance of those earning too much to qualify for education tax preferences. For the sake of completeness, though, I drop the high-income control group. The results from this specification indicate that there is a near-zero and insignificant effect of education tax preference eligibility on college attendance for the full sample of women and for the full sample of men. For female incomplete learners, the point estimate on Eligible is 0.014 with a standard error of 0.021 . For male incomplete learners, the Eligible coefficient is significant at the $10 \%$ level, with a point estimate of 0.026 and a standard error of 0.015. Dropping the high-income control group does not change the general pattern of results.

The instrument that I have constructed applies later-year tax law to income from 1997, just before any education tax preferences were available. Income from a single year will reflect both permanent income and transitory shocks particular to that year. The larger the transitory shocks, the weaker my instrument. To reduce the impact of transitory income shocks, I construct an alternative instrument. I average income from the two surveys prior to the availability of education tax preferences, corresponding to tax years 1995 and $1997 .^{19}$ I then apply later-

\footnotetext{
${ }^{18}$ According to the Welfare Rules Database assembled by the Urban Institute, in 1996, on the eve of federal welfare reform, there were 41 states (including D.C.) that allowed welfare recipients to be attending postsecondary education. In 1997, 27 states counted postsecondary education as satisfying a work requirement. There is some variation within states over time on this issue, and by 2005 there were 32 states in which postsecondary education satisfied a work requirement.

${ }^{19}$ For individuals who are present in the 1998 survey but not in the 1996 survey, I continue to use 1997 income
} 
year tax law to this average income, indexed for inflation. The results with this instrument are shown in row $\mathrm{F}$ of Table 7 . In this specification, tax preference eligibility is associated with a 2.9 percentage point increase in the probability of college attendance for male incomplete learners. The estimated effect of tax preference eligibility is insignificant for all other groups.

Next, I try replacing the eligibility dummy variable with the dollar value of potential benefit from education tax preferences. Dollar amounts are measured in thousands. This specification takes advantage of the additional variation in potential benefit size that is illustrated in Figure 2. This variation comes from cross-sectional variation in AGI and tax liability as well as from changes in the benefit computation over time. ${ }^{20}$ The results of the corresponding fixed effects IV estimates are shown in row $\mathrm{G}$ of Table 7. In this specification, there is again evidence of a college attendance response for male incomplete learners. Being eligible for $\$ 1000$ of educationrelated tax benefits is associated with a 2.8 percentage point increase in the probability of college attendance. The coefficient for female incomplete learners is also significant at the $10 \%$ level and is quite large, 3.5 percentage points.

Table 7 shows that, across several different specifications, eligibility for an education tax preference increases the college attendance of male incomplete learners by 2.5 to 3.4 percentage points. The effect for female incomplete learners is generally not significantly different from zero, although large standard errors make it impossible to rule out similar-sized effects for men and women. I have investigated several reasons why the responses of male and female incomplete learners might be different. First, it is plausible that the costs of adult college enrollment are lower for those who are closer to achieving their initial educational expectations. Men may have a stronger response to education tax preferences if they have smaller educational gaps to close. However, male incomplete learners are no closer to their expected educational attainment than are female incomplete learners. The gap between expected and actual years of only.

${ }^{20}$ When I replace the eligibility dummy with the dollar value of education tax preferences, it is possible to drop all ineligible individuals and estimate a regression identified solely from dollar value variation across eligible individuals. In practice, there is not sufficient variation in my dollar value estimates for this to be a meaningful exercise. The resulting estimates are extremely noisy. 
education is 2.6 years for male incomplete learners and 2.4 years for female incomplete learners. Second, it is possible that men face higher returns to mid-career college attendance because of gendered patterns of employment by industry. My data indicate that men are more likely to work in declining industries such as manufacturing, while women are more likely to be in growing industries such as education- and health-related services. If industry differences account for the significant response among men, then I should see a large response to tax preference eligibility among the set of all workers, men and women, initially employed in manufacturing. This pattern is not present in the data. Finally, the opportunity costs of adult college enrollment may be higher for women because they face substantial child care responsibilities. If this explains the different responses of men and women, then results for female incomplete learners without children should mirror the results for male incomplete learners. There is inconclusive support for this explanation. A regression for female incomplete learners without children under 6 at any point over 1997-2005 produces a large and imprecisely estimated coefficient, 0.027 with a standard error of 0.032 .

\subsection{Degree Completion}

The Lifetime Learning tax credit and the tuition deduction are not restricted to students enrolled in degree-granting programs. While students may derive satisfaction or useful skills from coursework that does not eventually lead to a degree, the labor market tends to reward degrees. For example, Jaeger and Page (1996) demonstrate that the labor market return to obtaining a diploma exceeds the return to merely completing the number of years of schooling typically associated with that degree. Despite the substantial return to completing a degree, Bound, Lovenheim, and Turner (2010) show that the share of the population with some college experience but no college degree is actually rising, particularly among men. Dynarski (2008) finds that degree completion among students of traditional college age is sensitive to costs. She shows that introduction of generous state merit scholarships for recent high school graduates in Arkansas and Georgia is associated with a 3 percentage point increase in the share of the population 
that has completed a college degree. If merit scholarships have increased degree completion among students of traditional college age, it is plausible that education tax preferences may have increased degree receipt among older students, many of whom have some earlier college experience. I next investigate whether eligibility for an education tax preference is associated with an increased probability of degree receipt.

In each of the NLSY79 survey rounds that I use, respondents who have reported attending college are asked if they have obtained any kind of academic degree since the last interview. I estimate fixed effects IV regressions in which the dependent variable is a dummy equal to one if a respondent answers yes to this question. ${ }^{21}$ The results of these regressions are shown in Table 8. There is no evidence that eligibility for an education tax preference affects the probability of degree receipt. For each group that I consider, the Eligible coefficient is statistically insignificant and quite close to zero. This is true in specifications using an eligibility dummy variable and in specifications that use the dollar value of education-related tax preferences for which an individual is eligible. It is also true when I restrict the sample to respondents with some previous college experience as of the 1997 interview.

\subsection{Heterogeneity of Responses by Savings Level}

The previous results demonstrate that, across a number of specifications, eligibility for an education tax credit or tuition deduction increases the probability of college attendance among men whose 1997 educational levels fall short of their 1979 expectations. Next I show that within this group, the response differs by level of savings. There will typically be a long lag between when a person pays higher education expenses and when he receives the benefit from an education tax credit or tuition deduction. For example, if a person enrolls in college and pays tuition in January of 2004, he can claim a credit or deduction when he files his 2004 tax return in the early months of 2005. This lag may not be problematic for individuals with liquid

\footnotetext{
${ }^{21}$ For respondents who have participated in all five interviews, the dependent variable always spans a two-year period. For respondents who have missed an interview, the dependent variable spans a longer period. In either case, the tax year in which eligibility is measured is a subset of the period over which degree receipt is measured.
} 
assets. However, it can limit the usefulness of the tax preferences to individuals who have low levels of assets and who face credit constraints.

I use information on asset values to identify individuals with low balances in savings accounts as of the 1998 interview. I divide the sample into those with a zero balance, those with a nonzero balance, and those with a balance above the median. About $28 \%$ of male incomplete learners had no money in a savings account as of the 1998 interview, and the median 1998 savings account balance for all male incomplete learners is $\$ 1750$. Panel A of Table 9 reports the results of college attendance regressions by savings level. For those with no money in a savings account, the coefficient on Eligible is near zero although very imprecisely estimated. For those with a non-zero savings account balance, eligibility for an education tax preference is associated with a 4.3 percentage point increase in the probability of college attendance. The effect is even larger, 5.0 percentage points, among those with more than the median level of savings. This pattern of results is consistent with the possibility that credit constraints prevent some eligible individuals from making use of education tax preferences.

The savings account balance measured at one point in time may be a very weak proxy for credit constraints. As an alternative, I average each individual's reported savings account balances from the years in which asset questions were included (1998, 2000, and 2004). About $13 \%$ of male incomplete learners have a zero average savings account balance, and the median value, measured in real 2005 dollars, is $\$ 3287$. This average balance is likely to suffer from less measurement error than is the savings account balance measured in one year only. On the other hand, it may be endogenous to college enrollment during my period of analysis. It is likely that adults who choose to enroll in college draw down their savings to pay for it. Panel B of Table 9 shows the results of dividing the sample on the basis of average savings account balances. For those with a zero average balance, the point estimate on the eligibility term is near zero. With only 717 observations in this regression, though, this is a very imprecise estimate. Among those with a non-zero average savings account balance, the coefficient on Eligible indicates a 3.4 percentage point college attendance response, significant at the $5 \%$ level. The estimated 
effect is again larger for those with above-median levels of savings.

\section{Conclusion}

The tax code plays an increasingly important role in the delivery of college financial aid. In 2005, federal spending on the Hope tax credit, Lifetime Learning tax credit, and tuition deduction was $\$ 8.5$ billion, slightly more than half of federal Pell grant spending. This paper makes two contributions to the growing literature on the effectiveness of tax-based college aid. First, it uses long-run panel data and fixed effects IV estimation to identify the college attendance response. Second, it focuses on adults in their 30s and 40s. The Lifetime Learning credit and the tuition deduction are available to students enrolled in as little as one college class, cover expenses for any year of college or graduate school, and can be claimed for an unlimited number of years. These features make the tax benefits accessible to adults returning to college after some time off and to those who are combining work and an occasional college course.

I use data from the 1998-2006 rounds of the NLSY79 to investigate how eligibility for an education tax preference affects the college attendance decision. I estimate fixed effects regressions, instrumenting for eligibility by applying current-year tax law to income as of 1997, just before tax provisions for college expenses were in effect. In the full sample of women and in the full sample of men, the decision to attend college is not affected by the tax credits or tuition deduction. There is evidence of a strong positive enrollment effect among a subsample of adult men, those whose educational expectations as teenagers had not been met as of 1998 . Among this group, about one-third of the full sample of men, being eligible for an education tax preference is associated with a 2.5 to 3.4 percentage point increase in the probability of college attendance. This effect is large and persistent across a number of robustness checks. Among the group of women whose initial educational expectations had not been met as of 1998, eligibility for an education tax preference does not affect college attendance.

The overlap between tax policy and postsecondary educational policy is growing. Students 
of traditional college age are not the only group in a position to benefit from tax-based college aid. This paper demonstrates that, between 1999 and 2005, education tax preferences increased college attendance among a particular subset of adult men. The potential for education tax preferences to promote college attendance among adults is likely to be even greater in a period of extended economic downturn, industrial restructuring, and high unemployment rates.

\section{References}

Belley, Philippe and Lance Lochner. 2007. "The Changing Role of Family Income and Ability in Determining Educational Achievement." Journal of Human Capital. 1(1): 37-89.

Betts, Julian R. and Laurel L. McFarland. 1995. "Safe Port in a Storm: The Impact of Labor Market Conditions on Community College Enrollments." Journal of Human Resources 30(4): 741-765.

Bound, John, Michael F. Lovenheim, and Sarah Turner. 2010. "Why Have College Completion Rates Declined? An Analysis of Changing Student Preparation and Collegiate Resources." American Economic Journal: Applied Economics 2(3): 129-157.

Burman, Leonard E., Elaine Maag, Peter Orszag, Jeffery Rohaly, and John O'Hare. 2005. "The Distributional Consequences of Federal Assistance for Higher Education: The Intersection of Tax and Spending Programs." Tax Policy Center Discussion Paper, No. 26.

Carroll, Robert, Douglas Holtz-Eakin, Mark Rider, and Harvey S. Rosen. 2000. "Income Taxes and Entrepreneurs' Use of Labor." Journal of Labor Economics 18(2): 324-351.

Cook, Bryan J. and Jacqueline E. King. 2007. 2007 Status Report on the Pell Grant Program. American Council on Education.

Corman, Hope. 1983. "Postsecondary Education Enrollment Responses by Recent High School Graduates and Older Adults." Journal of Human Resources 18(2): 247-267.

Cronin, Julie-Anne. 1997. "The Economic Effects and Beneficiaries of the Administration's Proposed Higher Education Tax Subsidies." National Tax Journal 50(3): 519-540.

DeNavas-Walt, Carmen, Bernadette D. Proctor, and Cheryl Hill Lee. 2006. "Income, Poverty, and Health Insurance Coverage in the United States: 2005." P60-231. U.S. Census Bureau. 
Dynarski, Susan. 2002. "The Behavioral and Distributional Implications of Aid for College." The American Economic Review, Papers and Proceedings 92(2): 279-285.

Dynarski, Susan. 2008. "Building the Stock of College-Educated Labor." Journal of Human Resources 43(3): 576-610.

Feenberg, Daniel and Elisabeth Coutts. 1993. "An Introduction to the TAXSIM Model." Journal of Policy Analysis and Management 12(1): 1889-194.

Goldin, Claudia, Lawrence F. Katz, and Ilyana Kuziemko. 2006. "The Homecoming of American College Women: The Reversal of the College Gender Gap." Journal of Economic Perspectives 20(4): 133-156.

Government Accounting Office. 2008. "Multiple Higher Education Tax Incentives Create Opportunities for Taxpayers to Make Costly Mistakes." GAO-08-717T.

Heller, Donald E. 1997. "Student Price Response in Higher Education: An Update to Leslie and Brinkman." The Journal of Higher Education 68(6): 624-659.

Hoxby, Caroline M. 1998. "Tax Incentives for Higher Education." Tax Policy and the Economy 12: 49-81.

Internal Revenue Service. Various years. Individual Complete Report. Washington, D.C.: Internal Revenue Service, Statistics of Income division.

Internal Revenue Service. 2000. Individual Income Tax Returns 1997. Publication 1304. Washington, D.C.: Internal Revenue Service, Statistics of Income division.

Jaeger, David A. and Marianne E. Page. 1996. "Degrees Matter: New Evidence on Sheepskin Effects in the Returns to Education." Review of Economics and Statistics." 78(4): 733-740.

Jacobson, Louis, Robert J. LaLonde, and Daniel Sullivan. 2005. "The Impact of Community College Retraining on Older Displaced Workers: Should We Teach Old Dogs New Tricks?" Industrial and Labor Relations Review 58(3): 398-415.

Jepsen, Christopher and Mark Montgomery. 2009. "Miles to Go Before I Learn: The Effect of Travel Distance on the Mature Person's Choice of a Community College." Journal of Urban Economics 65(1): 64-73.

Joint Committee on Taxation. 1997. "General Explanation of Tax Legislation Enacted in 1997." JCS-23-97.

Joint Committee on Taxation. 2005. "Estimates of Federal Tax Expenditures for Fiscal Years 2005-2009." JCS-1-05. 
Leslie, Larry L. and Paul T. Brinkman. 1987. "Student Price Response in Higher Education: The Student Demand Studies." The Journal of Higher Education 58(2): 181-204.

Leigh, Duane E. and Andrew M. Gill. 1997. "Labor Market Returns to Community Colleges: Evidence for Returning Adults." Journal of Human Resources 32(2): 334-353.

Light, Audrey. 1995. "The Effects of Interrupted Schooling on Wages." Journal of Human Resources 30(3): 472-502.

Long, Bridget Terry. 2004. "The Impact of Federal Tax Credits for Higher Education Expenses." In College Choices: The Economics of Where to Go, When to Go, and How to Pay for It, ed. Caroline Hoxby, 101-165. University of Chicago Press.

Seftor, Neil S. and Sarah E. Turner. 2002. "Back To School: Federal Student Aid Policy and Adult College Enrollment." Journal of Human Resources 37(2): 336-352.

Turner, Nicholas. 2010a. "The Effect of Tax-Based Federal Student Aid on College Enrollment." Working paper.

Turner, Nicholas. 2010b. "Why Don't Taxpayers Maximize their Tax-Based Student Aid Awards? Salience, Inertia, and Tax Evasion in Tax-Based Aid Selection." Working paper.

U.S. Department of Education. 2009. Digest of Education Statistics. Washington, D.C.: National Center for Education Statistics. 
Table 1: Description of Major Tax Preferences for Higher Education

\begin{tabular}{|c|c|c|c|c|c|c|c|}
\hline & \multicolumn{4}{|c|}{ Tax Credits } & \multicolumn{3}{|c|}{ Tuition Deduction } \\
\hline & \# of & Total & $\operatorname{Max}$ & $\operatorname{Max}$ & \# of & Total & Max \\
\hline & Returns & Dollars & Hope & LLTC & Returns & Dollars & Benefit \\
\hline & Claiming & Claimed & & & Claiming & Deducted & \\
\hline 1998 & $4,652,596$ & $3,376,647$ & 1500 & 1000 & & & \\
\hline 1999 & $6,436,654$ & $4,772,443$ & 1500 & 1000 & & & \\
\hline 2000 & $6,815,316$ & $4,851,178$ & 1500 & 1000 & & & \\
\hline 2001 & $7,212,554$ & $5,156,254$ & 1500 & 1000 & & & \\
\hline 2002 & $6,475,134$ & $4,882,853$ & 1500 & 1000 & $3,444,941$ & $6,154,145$ & 3000·MTR \\
\hline 2003 & $7,298,185$ & $5,842,966$ & 1500 & 2000 & $3,571,154$ & $6,683,631$ & 3000·MTR \\
\hline 2004 & $7,180,884$ & $6,016,805$ & 1500 & 2000 & $4,710,253$ & $10,589,279$ & 4000·MTR \\
\hline 2005 & $7,057,251$ & $6,119,631$ & 1500 & 2000 & $4,696,013$ & $10,846,990$ & 4000·MTR \\
\hline
\end{tabular}

Note: Data on the number of returns claiming each benefit and on the dollar values claimed come from annual versions of the Individual Complete Report published by the Statistics of Income division of the Internal Revenue Service. Data on the tax credits come from Table 3.3, All Returns: Tax Liability, Tax Credits, and Tax Payments. Data on the tuition deduction come from Table 1.4, All Returns: Sources of Income, Adjustments, and Tax Items. Total dollars claimed and total dollars deducted are in thousands. The maximum Hope amount is defined per student and the maximum Lifetime Learning credit amount is defined per return.

Table 2: Summary Statistics for Regression Sample

\begin{tabular}{lcc}
\hline \hline & Women & Men \\
\hline Age & 41 & 41 \\
\% Married & 66.7 & 66.5 \\
Number of Children in Household & 1.50 & 1.25 \\
\% with Any Children Under 6 & 42.5 & 59.7 \\
Mean Adjusted Gross Income & 69748 & 75559 \\
Median Adjusted Gross Income & 54146 & 60000 \\
\% Urban & 65.5 & 66.2 \\
\% with Any Unemployment & 7.4 & 7.6 \\
Weeks Worked Last Year & 40.0 & 46.2 \\
\% Eligible for Education Tax Preference & 48.5 & 51.9 \\
\% Attended College Last Year & 6.7 & 3.4 \\
\% Attaining Less Education than Expected & 33.2 & 34.7 \\
N & 17573 & 15942 \\
\hline \hline
\end{tabular}

Note: The table reports weighted means, using a year-specific weighting variable constructed by the NLSY staff. The unit of observation is the respondent-year. A respondent can be observed in one to five years. This table includes observations from 3552 men and 3832 women. Adjusted gross income is reported in real 2005 dollars. 
Table 3: Educational Expectations and Actual Years of Education

\begin{tabular}{|c|c|c|c|c|c|c|c|c|}
\hline \multirow{3}{*}{$\begin{array}{l}\text { Expected Years } \\
\text { Less than } 12\end{array}$} & \multicolumn{4}{|c|}{ Women } & \multicolumn{4}{|c|}{ Men } \\
\hline & 12 & $13-15$ & 16 & $>16$ & 12 & $13-15$ & 16 & $>16$ \\
\hline & 94 & 18 & 5 & 1 & 121 & 17 & 2 & 1 \\
\hline 12 & 1078 & 247 & 44 & 18 & 1120 & 200 & 31 & 14 \\
\hline $13-15$ & 339 & 383 & 77 & 36 & 314 & 201 & 48 & 16 \\
\hline 16 & 222 & 403 & 293 & 173 & 287 & 318 & 255 & 137 \\
\hline More than 16 & 43 & 110 & 114 & 134 & 53 & 118 & 134 & 165 \\
\hline
\end{tabular}

Note: Data on the number of years of education a respondent expects to complete come from 1979, the first round of the survey. All respondents were interviewed in this year, although a handful do not answer the educational expectation question. These respondents are categorized as expecting to complete fewer than 12 years of education.

Table 4: Comparison of Incomplete Learners and Others

\begin{tabular}{lcccc}
\hline \hline & \multicolumn{2}{c}{ Women } & \multicolumn{2}{c}{ Men } \\
& $\begin{array}{c}\text { Incomplete } \\
\text { Learners }\end{array}$ & Others & $\begin{array}{c}\text { Incomplete } \\
\text { Learners }\end{array}$ & Others \\
\hline A. Summary Statistics at Respondent Level & & & & \\
Educational Expectation as of 1979 & 15.6 & 13.4 & 15.8 & 13.4 \\
Educational Attainment as of 1998 & 13.3 & 14.1 & 13.3 & 14.0 \\
Age at First Interview & 17.7 & 17.8 & 18.0 & 17.7 \\
\% White & 75.0 & 83.8 & 74.0 & 83.1 \\
N & 1378 & 2454 & 1313 & 2239 \\
B. Summary Statistics at Respondent-Year Level & & & \\
\% Married & 64.4 & 67.8 & 64.7 & 67.4 \\
Number of Children in Household & 1.54 & 1.48 & 1.24 & 1.25 \\
\% with Any Children Under 6 & 39.8 & 43.8 & 60.5 & 59.3 \\
Mean Adjusted Gross Income & 66489 & 71371 & 74354 & 76200 \\
Median Adjusted Gross Income & 51500 & 55612 & 59668 & 60000 \\
\% Urban & 68.6 & 63.9 & 71.0 & 63.7 \\
\% with Any Unemployment & 7.8 & 7.1 & 8.2 & 7.3 \\
Weeks Worked Last Year & 39.2 & 40.4 & 45.9 & 46.4 \\
\% Eligible for Education Tax Preference & 49.2 & 48.2 & 51.8 & 51.9 \\
\% Attended College Last Year & 8.1 & 6.0 & 4.0 & 3.1 \\
N & 6329 & 11244 & 5887 & 10055 \\
\hline \hline
\end{tabular}

Note: The table reports weighted means, using a year-specific weighting variable constructed by the NLSY staff. Dollar amounts are reported in real 2005 dollars. 


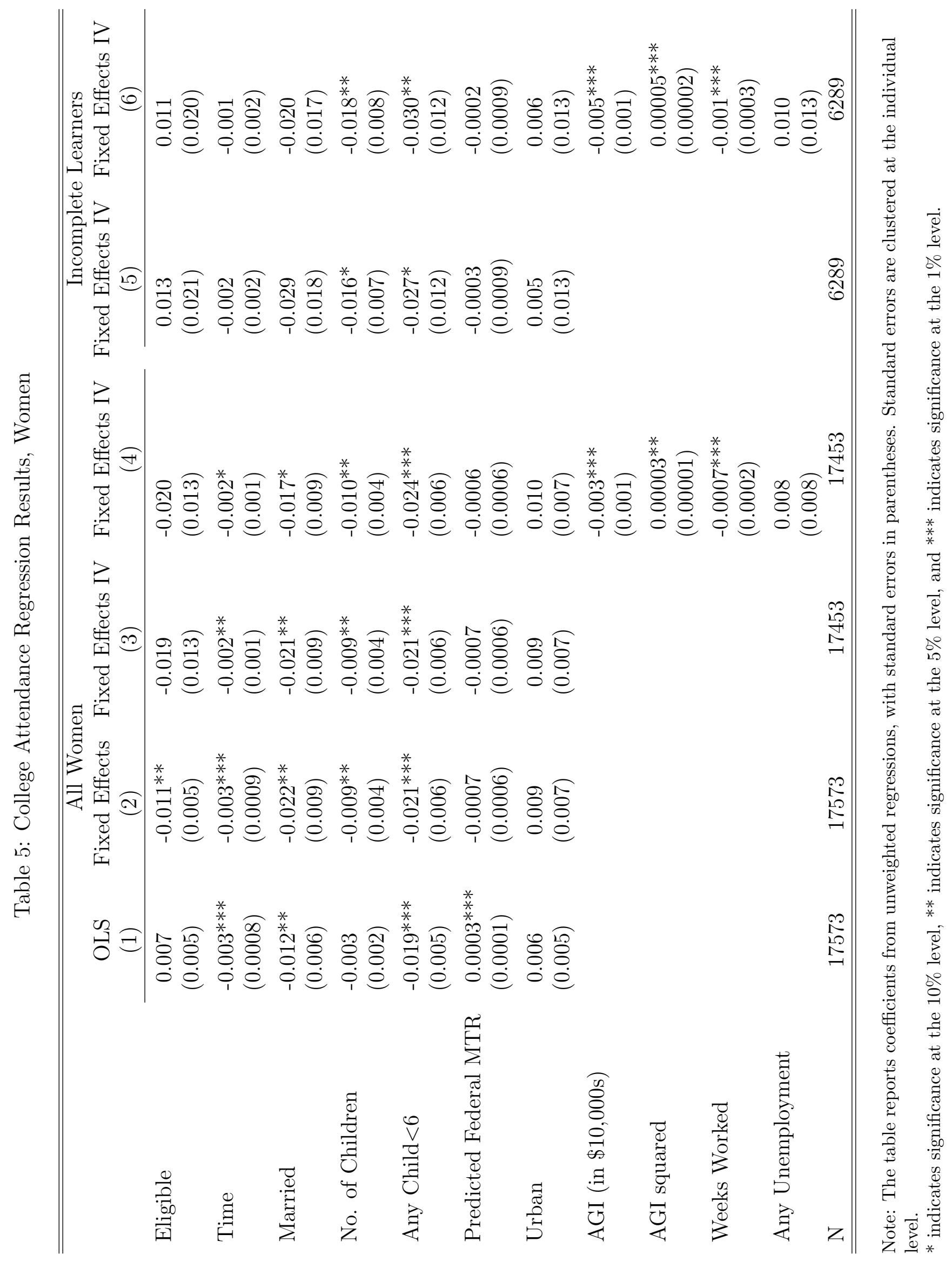




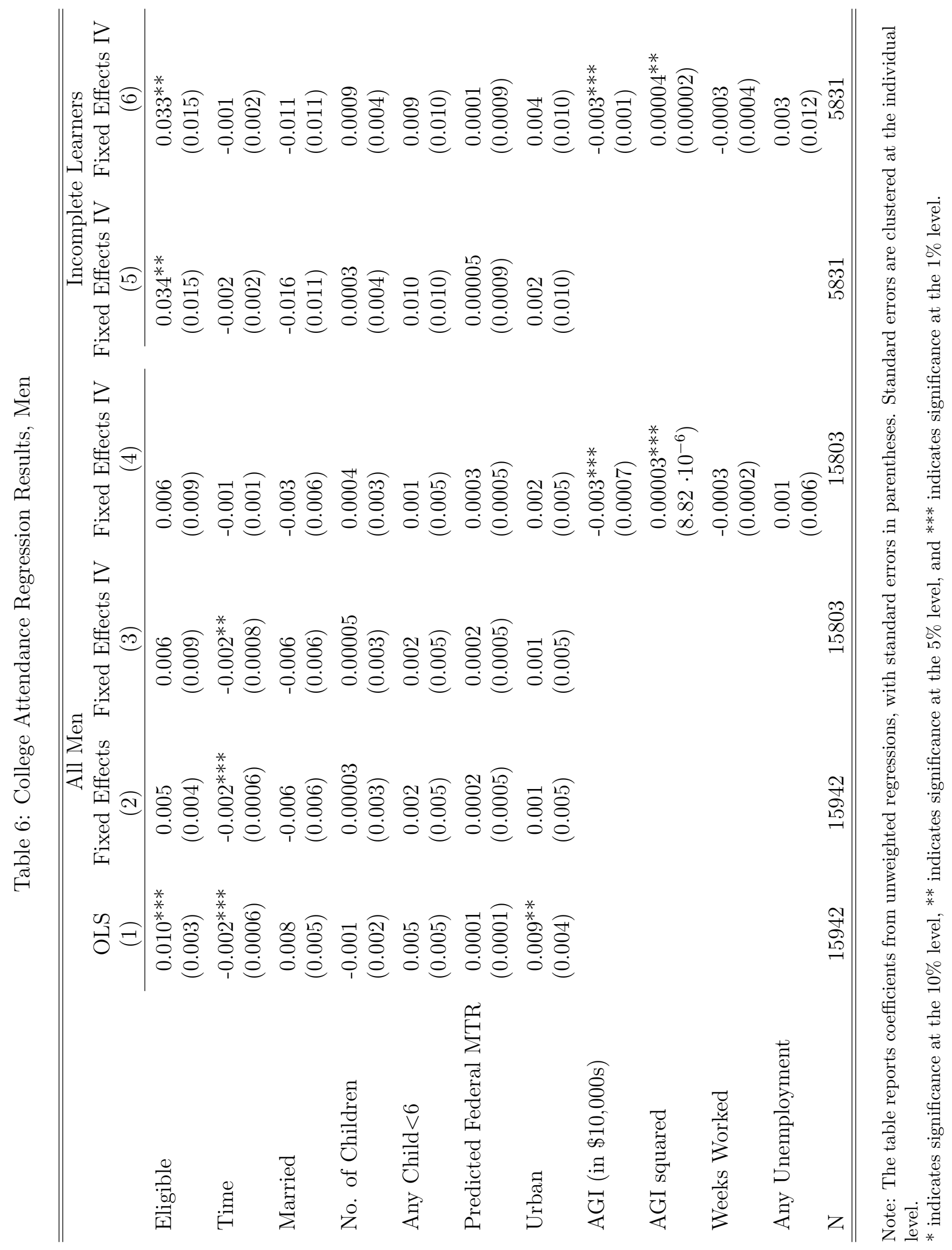


Table 7: Robustness Checks: Coefficients on Eligible, Fixed Effects IV Regressions

\begin{tabular}{|c|c|c|c|}
\hline All Women & All Men & $\begin{array}{c}\text { Female } \\
\text { Incomplete } \\
\text { Learners }\end{array}$ & $\begin{array}{c}\text { Male } \\
\text { Incomplete } \\
\text { Learners }\end{array}$ \\
\hline $\begin{array}{c}\text { A. Baseline } \\
-0.019 \\
(0.013)\end{array}$ & $\begin{array}{c}0.006 \\
(0.009)\end{array}$ & $\begin{array}{c}0.013 \\
(0.021)\end{array}$ & $\begin{array}{c}0.034^{* *} \\
(0.015)\end{array}$ \\
\hline $\begin{array}{c}\text { B. Setting Be } \\
-0.014 \\
(0.009)\end{array}$ & $\begin{array}{c}\text { efit }=0 \text { for } \\
0.005 \\
(0.007)\end{array}$ & $\begin{array}{c}\text { Reported No } \\
0.001 \\
(0.016)\end{array}$ & $\begin{array}{c}\text {-Filers } \\
0.028^{* *} \\
(0.011)\end{array}$ \\
\hline $\begin{array}{c}\text { C. Dropping } \\
-0.019 \\
(0.013)\end{array}$ & $\begin{array}{c}\text { eported } N \\
0.004 \\
(0.009)\end{array}$ & $\begin{array}{c}n \text {-Filers } \\
0.014 \\
(0.022)\end{array}$ & $\begin{array}{c}0.031^{*} \\
(0.016)\end{array}$ \\
\hline $\begin{array}{l}\text { D. Assuming } \\
-0.020^{*} \\
(0.012)\end{array}$ & $\begin{array}{c}\text { Tandard } 1 \\
0.005 \\
(0.008)\end{array}$ & $\begin{array}{c}\text { duction } \\
0.020 \\
(0.021)\end{array}$ & $\begin{array}{c}0.025^{*} \\
(0.015)\end{array}$ \\
\hline $\begin{array}{c}\text { E. Dropping } \\
-0.018 \\
(0.013)\end{array}$ & $\begin{array}{c}\text { ow-Incom } \\
0.004 \\
(0.008)\end{array}$ & $\begin{array}{c}\text { Ineligibles } \\
0.003 \\
(0.021)\end{array}$ & $\begin{array}{l}0.034^{* *} \\
(0.015)\end{array}$ \\
\hline $\begin{array}{l}\text { F. Instrument } \\
\quad-0.018 \\
\quad(0.013)\end{array}$ & $\begin{array}{c}U \text { sing Tu } \\
0.004 \\
(0.009)\end{array}$ & $\begin{array}{l}\text { Years of In } \\
0.009 \\
(0.022)\end{array}$ & $\begin{array}{c}\text { ome Data } \\
0.029^{*} \\
(0.016)\end{array}$ \\
\hline $\begin{array}{c}\text { G. Replacing } \\
0.014 \\
(0.011)\end{array}$ & $\begin{array}{c}\text { Eligibility } \\
0.008 \\
(0.008)\end{array}$ & $\begin{array}{l}\text { ummy with } \\
0.035^{*} \\
(0.019)\end{array}$ & $\begin{array}{c}\text { ollar Amount } \\
0.028^{* *} \\
(0.014)\end{array}$ \\
\hline
\end{tabular}

Note: Each cell of the table represents a separate regression. Standard errors are clustered at the individual level.

* indicates significance at the $10 \%$ level, $* *$ indicates significance at the $5 \%$ level, and $* * *$ indicates significance at the $1 \%$ level. 
Table 8: Degree Completion Results, Fixed Effects IV Regressions

\begin{tabular}{cccc}
\hline \hline All Women & All Men & $\begin{array}{c}\text { Female } \\
\text { Incomplete } \\
\text { Learners }\end{array}$ & $\begin{array}{c}\text { Male } \\
\text { Incomplete } \\
\text { Learners }\end{array}$ \\
\hline A. Eligibility Dummy & & \\
0.002 & -0.004 & 0.007 & -0.0002 \\
$(0.008)$ & $(0.006)$ & $(0.010)$ & $(0.010)$ \\
B. Dollar Value of Education Tax Preference (1000s) \\
0.0002 & -0.006 & 0.013 & -0.003 \\
$(0.006)$ & $(0.004)$ & $(0.009)$ & $(0.008)$ \\
\hline \hline
\end{tabular}

Note: Each cell of the table represents a separate regression. Standard errors are clustered at the individual level.

* indicates significance at the $5 \%$ level and $* *$ indicates significance at the $1 \%$ level.

Table 9: Heterogeneity of Responses by Savings Level, Male Incomplete Learners

\begin{tabular}{|c|c|c|c|}
\hline & $\begin{array}{c}\text { Zero } \\
\text { Balance }\end{array}$ & $\begin{array}{c}\text { Non-Zero } \\
\text { Balance }\end{array}$ & $\begin{array}{l}\text { Above } \\
\text { Median }\end{array}$ \\
\hline \multicolumn{4}{|c|}{ A. Using 1998 savings account balance } \\
\hline & $\begin{array}{l}-0.006 \\
(0.046)\end{array}$ & $\begin{array}{l}0.043^{* * *} \\
(0.016)\end{array}$ & $\begin{array}{c}0.050^{* *} \\
(0.020)\end{array}$ \\
\hline $\mathrm{N}$ & 1612 & 4207 & 2903 \\
\hline \multicolumn{4}{|c|}{ B. Using average savings account balance } \\
\hline & $\begin{array}{l}-0.005 \\
(0.052)\end{array}$ & $\begin{array}{c}0.034^{*} \\
(0.016)\end{array}$ & $\begin{array}{c}0.049^{*} \\
(0.021)\end{array}$ \\
\hline $\mathrm{N}$ & 717 & 5110 & 2955 \\
\hline
\end{tabular}

Note: The table reports coefficients and standard errors on the Eligible variable from fixed effects IV regressions. The sample is restricted to men whose 1979 report of expected educational attainment exceeds the level of attainment attained as of the 1998 interview. Standard errors are clustered at the individual level.

* indicates significance at the $10 \%$ level, ${ }^{* *}$ indicates significance at the $5 \%$ level, and ${ }^{* * *}$ indicates significance at the $1 \%$ level. 
Figure 1: College Attendance Rates

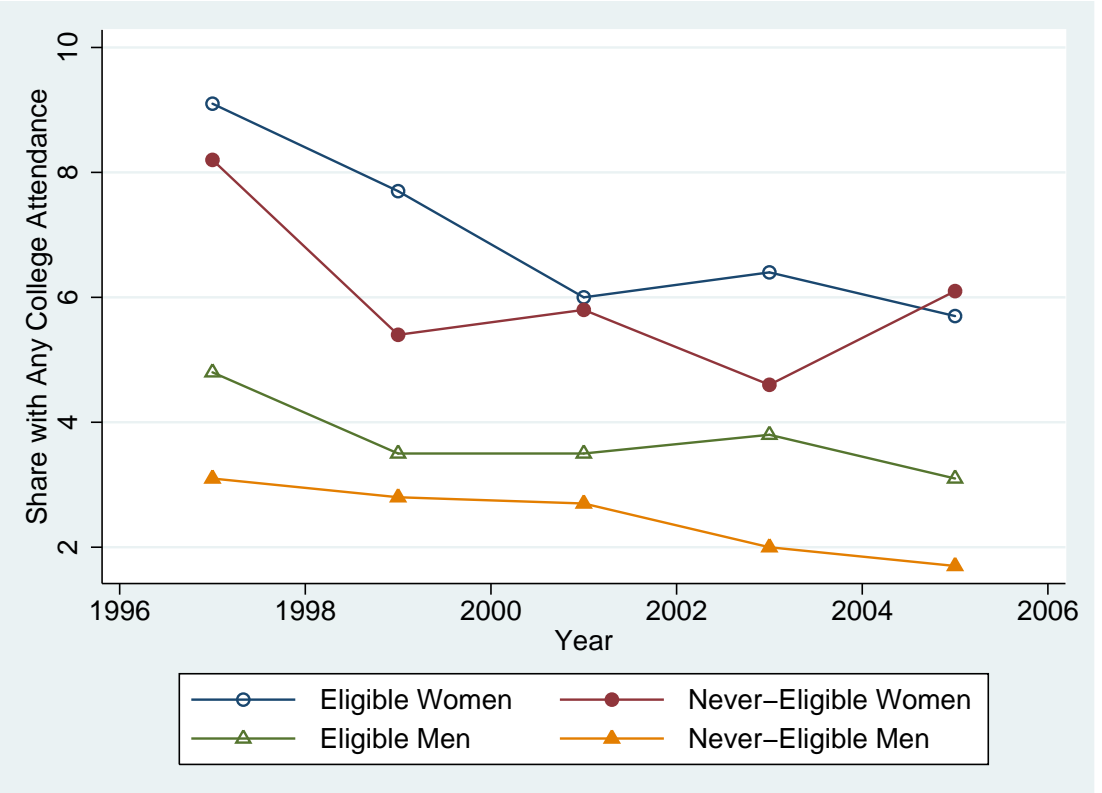


Figure 2: Benefits from Education Tax Preferences, by AGI

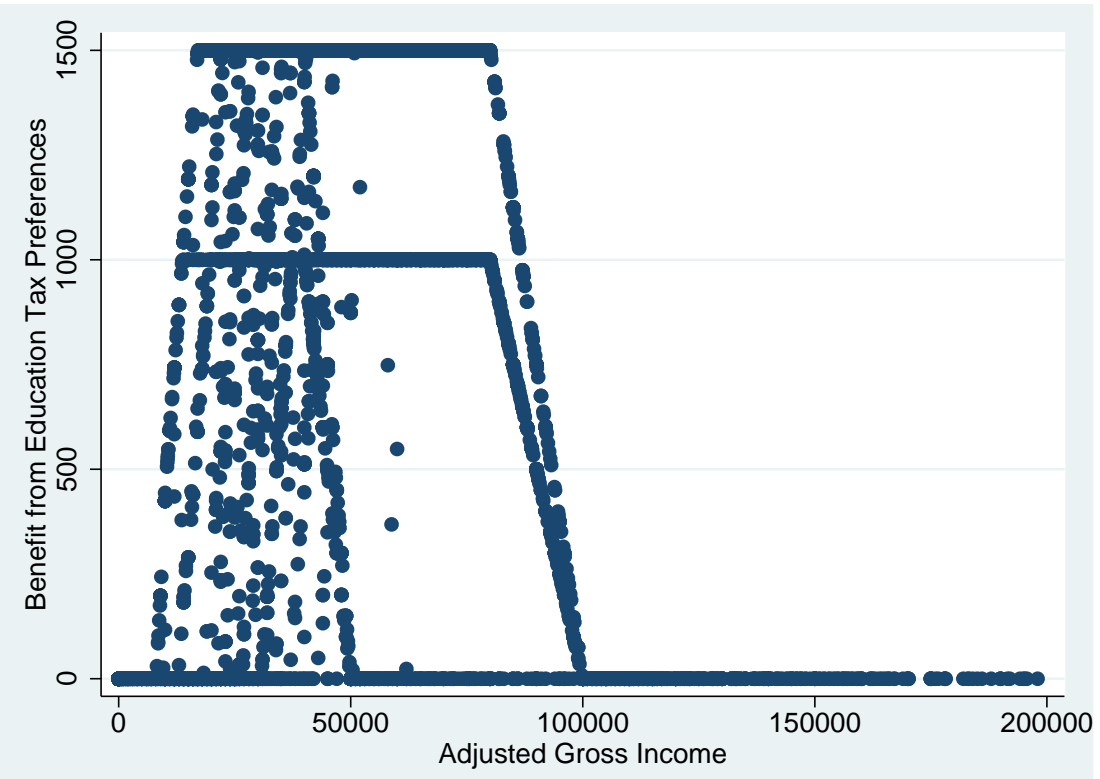

(a) 1999

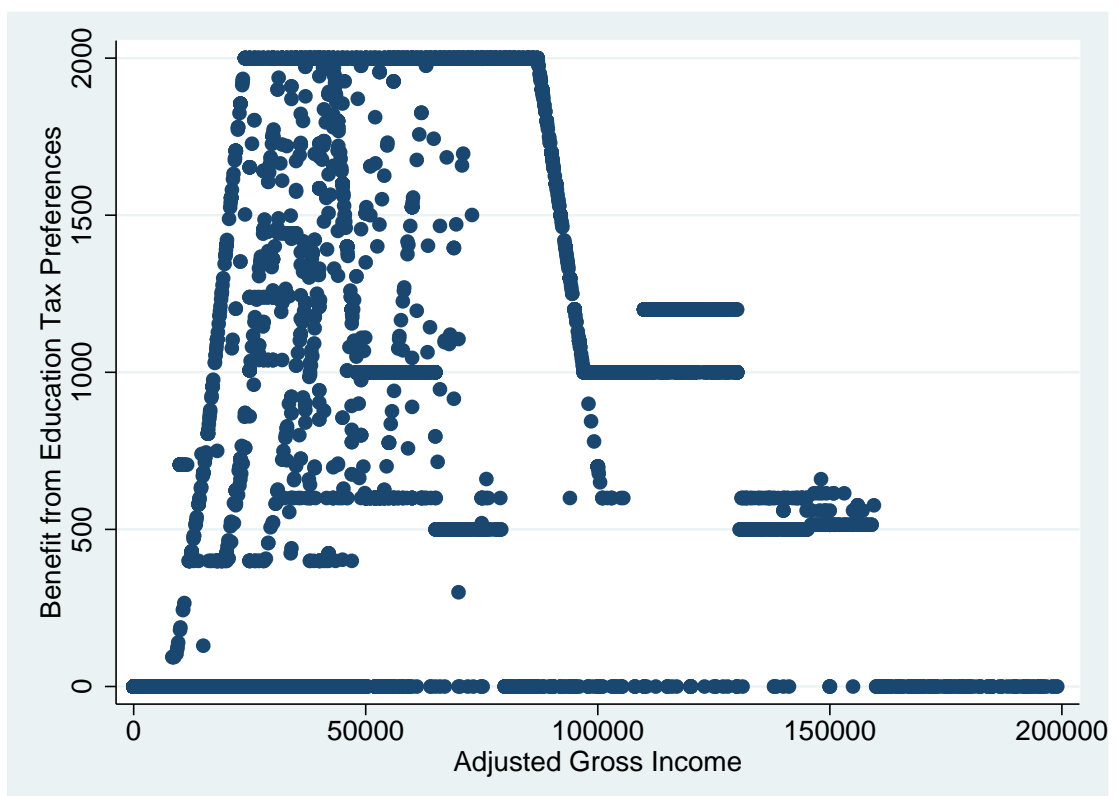

(b) 2005

Note: Dollar amounts are reported in nominal terms. Respondents with AGI above $\$ 200,000$, all of whom receive zero benefit from education tax preferences, are omitted from the figure. 